\title{
ERRATUM
}

\section{Gene therapy of melanoma pulmonary metastasis by intramuscular injection of plasmid DNA encoding tissue inhibitor of metalloproteinases-1}

\section{Yufei Shi, Ranjit S Parhar, Minjing Zou, Futwan A Al-Mohanna, and}

Malcolm C Patterson

Cancer Gene Therapy (2002) 9, 126-132 DOI: 10.1038/sj/cgt/7700426

Since the publication of this paper, the authors have identified errors in the content. A revised version of Figure 6, and an addition to the acknowledgments are given below.

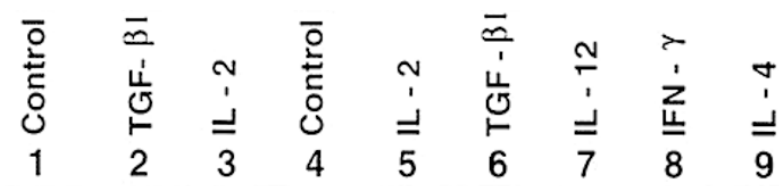
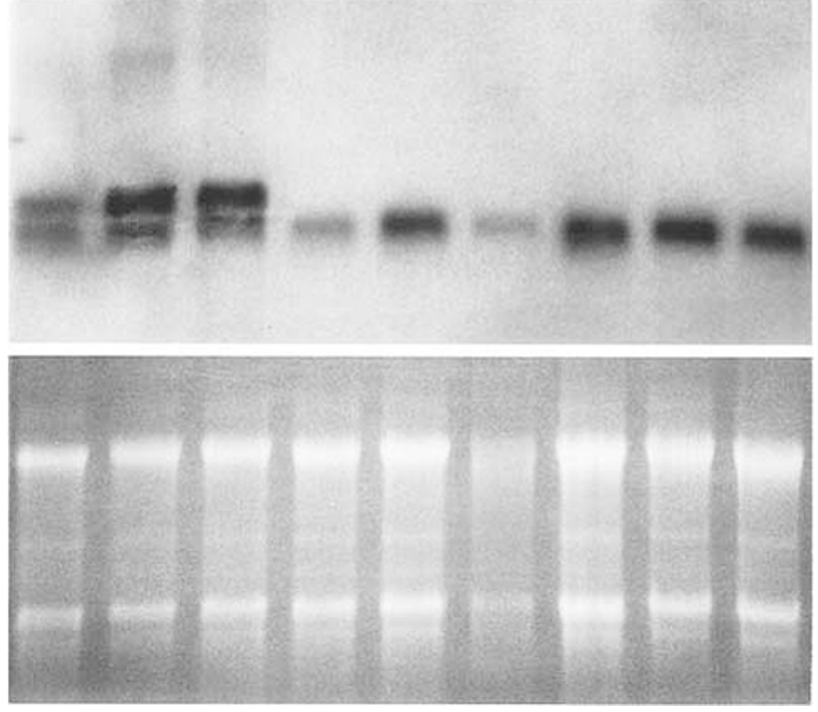

Figure 6

\section{Acknowledgments}

We thank Drs. Shaheen Nakeeb and Raafat M El-Sayed from the Animal Facility for their excellent support. This work was funded by the Research Centre, KFSH\&RC.

Received November 2, 2001

Address correspondence and reprint requests to: Dr Yufei Shi, MBC 3, Department of Biological and Medical Research, King Faisal Specialist Hospital and Research Centre, PO Box 3354, Riyadh 11211, Saudi Arabia. E-mail: yufei@kfshrc.edu.sa 